\title{
Dried beet pulp, pressed beet pulp and maize silage as substitutes for concentrates in dairy cow rations. 1. Feeding value, feed intake, milk production and milk composition
}

\author{
H. DE VISSER \& V. A. HINDLE
}

Research Institute for Livestock Feeding and Nutrition (IVVO), P.O. Box 160, NL 8200 AD Lelystad, Netherlands

Received 9 March 1989; accepted 15 November 1989

\begin{abstract}
A feeding trial was carried out with 48 dairy cows in second or later lactation. The experiment started immediately after parturition and lasted for 13 weeks. Basal diets consisted of a mixture of artificially dried grass and maize silage as roughage components and concentrates based on a mixture of by-product feeds. Additional to the basal diet, dried beet pulp, ensiled pressed beet pulp or maize silage was fed. Two groups received either dried beet pulp (DP) or ensiled pressed beet pulp (PP). The third group received extra maize silage (M). All rations were fed as totally mixed rations (TMR) to prevent selection. Digestibility of the ration components was determined with in vitro and in vivo methods. The feeding value of both types of beet pulp and maize silages agreed with that reported in literature. Total dry matter intake differed significantly between DP and the other groups (PP and M). Energy intake was highest for DP and lowest for group M. Milk yield was similar for all groups. However, group PP displayed an apparently different pattern with higher peak production than group M. Fat content and fat yield were similar for all groups. Milk protein yield did not differ significantly between groups, group $M$ tended to have the lowest production. Milk protein percentage did not differ between the groups, although group $\mathbf{M}$ showed a tendency to be lowest. The calculated energy balance agreed with liveweight changes.
\end{abstract}

Keywords: cow, digestibility, intake, milk production, beet pulp, pressed beet pulp, maize silage

\section{Introduction}

Use of by-product feeds as animal feedstuffs is very common in the Netherlands. Concentrates used in dairy cow feeding consist almost exclusively of by-products. Particularly by-products from the sugar industry, such as beet pulp, are highly appreciated feedstuffs, because of their quality and high level of digestibility. Increasing drying costs have led to the introduction of alternative methods of storage and 
feeding. The moist pulp, directly after processing, has a dry matter content of approximately $10 \%$. Pressing this material increases the dry matter content to between 18 and $25 \%$, reducing transport costs and improving ensiling characteristics.

Concentrates provide the animal with energy and protein in addition to that supplied by the roughage part of the diet. Part of the concentrate mixture can be replaced by single energy sources, such as dried or moist ensiled beet pulp. An alternative to such energy sources is the increase of an energy-rich roughage component, such as maize silage. Although a fair amount of information is available on the nutrition characteristics, such as palatability, digestibility and feeding value of a new feedstuff, the information on dried and ensiled pressed beet pulp originating from the same batch is very limited.

Therefore, it was decided to make a comparative study of the influence of ensiled pressed beet pulp, dried beet pulp and maize silage on production characteristics of dairy cows in early lactation. Objectives of this study were:

1. To measure the nutritive value of ensiled pressed beet pulp in vitro and in vivo.

2. To evaluate pressed beet pulp as a dietary ingredient in a feeding trial with dairy cows.

3. To measure the effects of introduction of pressed beet pulp in dairy rations on rumen fermentation characteristics.

This paper deals with the results of the first two objectives. The results of the rumen fermentation study will be reported in a subsequent paper.

\section{Materials and methods}

A feeding trial was performed with 3 groups of 16 animals of the Dutch Friesian Black and White or Dutch Friesian $\times$ Holstein Friesian breed. The animals were in second (approx. $40 \%$ ) or later lactation. The average age of the animals at the start of the experiment was 4 years and 6 months. The animals were grouped in blocks, based on their previous performances (milk production and composition). Within each block, animals were allocated at random to one of the treatment groups. The trial started immediately after parturition and lasted for 13 weeks. Experimental treatments were the diets. In addition to a basal diet of artificially dried grass $(20 \%$ of DM), maize silage ( $20 \%$ of DM) and a concentrate mixture (35\% of DM), $25 \%$ of the dry matter was fed as pressed beet pulp, dried beet pulp or extra maize silage (treatment groups PP, DP and M, respectively). To avoid selection by the animals the rations were offered as completely mixed diets and prepared using a mixing feeding wagon. Feed was offered twice daily; $40 \%$ at 5:00 h and $60 \%$ at 15:00 h. To compensate for the lower energy value of maize silage compared to both beet pulps, the amount of extra maize silage was reduced by $2 \%$ and substituted with concentrates. The concentrate mixture consisted of coconut expeller $(5 \%)$, maize gluten feed $(38.5 \%)$, palm kernel expeller $(8.3 \%)$, soya bean meal solv. extract $(24.3 \%)$, soya bean hulls $(15.0 \%)$, cane molasses $(5 \%)$, salt $(1 \%)$, calcium carbonate $(0.3 \%)$, dicalcium phosphate $(1.3 \%)$, vitamins and minerals $(0.5 \%)$, magnesium oxide $(0.8 \%)$.

Ration ingredients were analysed for dry matter, ash, nitrogen, crude fat, neutral 
detergent fibre (NDF), starch and sugars. Ensiled pressed beet pulp and maize silages were also analysed for volatile fatty acids, lactic acid and pH. DM was determined at $105^{\circ} \mathrm{C}$ and subsequently corrected for losses through volatiles. OM was calculated as weight loss upon ashing at $550^{\circ} \mathrm{C}$. Nitrogen was determined by the Dumas method (Merz, 1979). NDF was determined by the procedure described by Robinson et al. (1986). Starch, crude fat and sugars were determined according to the procedures of the Netherlands Normalisation Institute (NEN 3574, NEN 3576 and NEN 3571, respectively). Volatile fatty acids and lactic acid were analysed using gaschromatography as described by Robinson et al. (1986).

In vitro digestibility of organic matter was determined for all components (Tilley \& Terry, 1963; and IVVO modifications, van der Meer, pers. comm.). Artificially dried grass, dried beet pulp, pressed beet pulp, and some of the maize silages were also investigated for in vivo digestibility using wethers fed at maintenance, according to the method described by van Es \& van der Meer (1980).

The amount of feed offered to dairy cows in the feeding trial was based on restricted ad libitum feeding (approx. $2 \%$ residues). Animals were fed individually and daily refusals recorded. Milk yield was measured each week on two consecutive days by means of a Tru tester (Moderniek, Soest). At the same time samples were collected for analysis of milk fat and protein. Milk samples were preserved with sodium azide and analysed at a commercial laboratory (Stichting melkcontrolestation 'Noord', the Netherlands). Liveweight of the animals was measured the day after parturition and once a week for the duration of the trial. Bodyweight losses were calculated. The energy balance was calculated and adjusted for mobilization of body reserves.

Statistical examination of the results using variance analysis techniques was accomplished using the statistical programme Genstat (Alvey et al., 1982).

\section{Results}

The chemical compositions of the roughages are shown in Table 1 and those of the concentrate mixture, dried beet pulp and pressed beet pulp in Table 2 .

Dried and pressed beet pulp had similar proportions of ash, $\mathrm{N}$-Dumas, crude fibre and crude fat. The sugar content was lowest in the pressed beet pulp, this is probably as a result of the conversion of sugars into volatiles during the ensiling process and due to losses of sugar during the pressing process. The latter would also explain the difference in NDF content between the dried and pressed beet pulp. Maize silages from different batches were similar in ash, $\mathrm{N}$-Dumas and crude fat contents, but varied in crude fibre and NDF, due to time of harvesting and/or stage of maturity.

The in vitro determinations for the organic matter digestibilities of dried beet pulp, ensiled pressed beet pulp and maize silage (Table 3) agreed favourably with previous studies (Verite, 1975; Kelly, 1983; de Visser \& Tamminga, 1987; Moran et al., 1988).

The in vivo digestibility of the organic matter of the dried beet pulp and ensiled pressed beet pulp from the same origin was high and showed a relatively low variation (Table 4). The results agreed with the literature (Kelly, 1983; de Visser \& Tam- 
Table 1. Chemical composition of artificially dried grass and maize silages in feeding trial ( $\mathrm{g} \mathrm{kg}^{-1} \mathrm{DM}$ ).

\begin{tabular}{|c|c|c|c|c|c|c|}
\hline & \multirow{2}{*}{$\begin{array}{l}\text { Artificially } \\
\text { dried grass }\end{array}$} & \multicolumn{5}{|c|}{ Maize silage } \\
\hline & & 11 & 12 & B & D & large silo \\
\hline Dry matter & 835 & 265 & 242 & 264 & 286 & 256 \\
\hline Ash & 127 & 57 & 56 & 58 & 52 & 60 \\
\hline N-Dumas & 36 & 15 & 16 & 14 & 12 & 15 \\
\hline Crude fibre & 261 & 209 & 232 & 236 & 215 & 249 \\
\hline Crude fat (40/60 PE) & 30 & 29 & 28 & 29 & 29 & 28 \\
\hline Neutral detergent fibre & 553 & 442 & 464 & 456 & 457 & 495 \\
\hline Starch & - & 216 & 220 & 232 & 284 & 226 \\
\hline Sugars & 55 & - & - & - & - & - \\
\hline Acetic acid & - & 27 & 32 & 14 & 9 & 17 \\
\hline Lactic acid & - & & & 46 & & \\
\hline $\mathrm{pH}$ & - & 4.0 & 4.1 & 4.0 & 3.9 & 4.1 \\
\hline
\end{tabular}

Table 2. Chemical composition of the concentrate mixture, dried beet pulp and pressed beet pulp in feeding trial $\left(\mathrm{g} \mathrm{kg}^{-1} \mathrm{DM}\right)$.

\begin{tabular}{lccc}
\hline & Concentrate & Dried pulp & Pressed pulp \\
& & & \\
Dry matter & 864 & 897 & 185 \\
Ash & 102 & 86 & 86 \\
N-Dumas & 38 & 16 & 16 \\
Crude fibre & 137 & 206 & 206 \\
Crude fat (40/60 PE) & 36 & 4 & 5 \\
Neutral detergent fibre & 395 & 450 & 530 \\
Starch & 84 & - & - \\
Sugars & 74 & - & 35 \\
Acetic acid & - & - & 71 \\
Lactic acid & - & - & 35 \\
pH & - & & 4.1 \\
\hline
\end{tabular}

Table 3. In vitro digestibility and energy value of maize silage, dried beet pulp and pressed beet pulp.

\begin{tabular}{clll}
\hline Product & $\begin{array}{l}\text { In vitro } \\
\text { digestibility }\end{array}$ & SE & $\begin{array}{l}\text { NEL1 } \\
\text { (MJ) }\end{array}$ \\
Maize silage 11 & 72.8 & 0.8 & 6.12 \\
12 & 72.8 & 0.8 & 6.15 \\
B & 69.1 & 0.5 & 5.99 \\
D & 73.3 & 1.1 & 6.27 \\
large silo & 69.9 & 1.4 & 5.87 \\
Dried beet pulp & 89.5 & 0.5 & 7.32 \\
Pressed beet pulp & 87.5 & 0.1 & 7.18 \\
\hline
\end{tabular}

1 NEL = net energy lactation, according to the Dutch energy system (van Es, 1978) by means of in vitro organic matter digestibility. 
Table 4. The in vivo digestibility and calculated net energy values and digestible crude protein values of some of the maize silages, dried beet pulp and pressed beet pulp.

\begin{tabular}{|c|c|c|c|c|c|c|c|c|}
\hline \multirow[t]{2}{*}{ Product } & \multicolumn{6}{|c|}{ Digestibility coefficient ${ }^{1}$} & \multirow{2}{*}{$\begin{array}{l}\mathrm{NEL}^{2} \\
\mathrm{MJ} \mathbf{k g}^{-1} \\
\mathrm{DM}\end{array}$} & \multirow{2}{*}{$\begin{array}{l}\mathrm{dcp}^{3} \\
\mathrm{~g} \mathrm{~kg}^{-1} \\
\mathrm{DM}\end{array}$} \\
\hline & DM & OM & $\mathrm{cp}$ & cfat & cf & NFE & & \\
\hline Maize silage 11 & 71 & 74 & 61 & 78 & 66 & 78 & 6.22 & 57 \\
\hline D & 71 & 73 & 55 & 78 & 67 & 78 & 6.29 & 41 \\
\hline large silo & 68 & 71 & 55 & 79 & 63 & 76 & 5.95 & 52 \\
\hline Dried beet pulp & 83 & 89 & 68 & -25 & 87 & 95 & 7.24 & 68 \\
\hline Pressed beet pulp & 84 & 90 & 69 & -82 & 88 & 95 & 7.30 & 69 \\
\hline
\end{tabular}

$1 \mathrm{DM}=$ dry matter; $\mathrm{OM}=$ organic matter; $\mathrm{cp}=$ crude protein; $\mathrm{cfat}=$ crude fat; $\mathrm{cf}=$ crude fibre; NFE $=$ N-free extract.

2 NEL = net energy lactation, according to the Dutch energy system (van Es, 1978).

${ }^{3} \mathrm{dcp}=$ digestible crude protein; $\mathrm{cp}=$ crude protein.

minga, 1987). The digestibility of the crude protein of both the dried beet pulp and the ensiled pressed beet pulp was low (68 and 69, respectively), yet agreed favourably with previous experiments (Kelly, 1983; de Visser \& Tamminga, 1987). Especially the digestibility coefficients for $\mathrm{N}$-free extracts and crude fibre were high, yet in agreement with the results found by Cottyn et al. (1980) and de Visser \& Tamminga (1987). In spite of small differences in digestibility and chemical composition between the dried beet pulp and ensiled pressed beet pulp used in this experiment, the net energy (NEL) and digestible crude protein ( $(\mathrm{cp})$ values were almost equal. Using the actual in vivo digestibility values to calculate NEL and dcp the results were 7.24, $7.30 \mathrm{NEL}$ and $68,69 \mathrm{dcp}$ for dried beet pulp and ensiled pressed beet pulp, respectively.

The in vitro digestibilities of the maize silages used were similar (Table 3). The lower digestibility of the maize silage from the large silo could be explained from its chemical composition, because this silage was very high in crude fibre content compared to the other batches. The average digestibility was similar to what was found in other experiments (Steg, unpublished; Verite, 1975; Moran et al., 1988). The in vitro digestibility of maize silage was lower than that of the dried or pressed beet pulp (Table 3). These results agree with other experiments (Steg, unpublished; Cottyn et al., 1980). The in vivo digestibility of the different batches of maize silage were similar (Table 4). Again the maize silage from the large silo was lower than the other batches that were investigated. The in vitro and in vivo organic matter digestibilities were comparable with each other.

The beet pulps showed a better in vivo digestibility than the maize silage, confirming earlier findings (Verite, 1975; Cottyn et al., 1980; Steg, unpublished). The most important differences in digestibility between beet pulp and maize silage were found in crude fibre and $\mathrm{N}$-free extracts. Both fractions were highly digestible in beet pulp, but to a lesser extent digestible in maize silage (Table 4). This could be explained by the fact that maize silage contains a larger rumen-undegradable organic matter fraction compared to beet pulp, as shown by the results of incubations into the ru- 
men, using nylon bag incubations (Table 5).

The estimated net energy and the digestible crude protein ( $\mathrm{dcp}$ ) values of the maize silages, dried beet pulp and pressed beet pulp are shown in Table 4 . The values for the artificially dried grass and the concentrates were 5.36 and $6.96 \mathrm{MJ} \mathrm{kg}^{-1}$ $\mathrm{DM}$ and 164 and $191 \mathrm{dcp} \mathrm{kg}^{-1} \mathrm{DM}$, respectively.

Table 5. Characteristics of degradability of the organic matter.

\begin{tabular}{lllll}
\hline Rations & $\begin{array}{l}\text { Soluble } \\
\text { fraction } \\
(\%)\end{array}$ & $\begin{array}{l}\text { Digestible } \\
\text { fraction } \\
(\%)\end{array}$ & $\begin{array}{l}\text { Undigestible } \\
\text { fraction } \\
(\%)\end{array}$ & $\begin{array}{l}\text { Rate of } \\
\text { degradation } \\
(\%) \text { per hour) }\end{array}$ \\
Dried beet pulp & 6.3 & 88.0 & 5.7 & 5.59 \\
Pressed beet pulp & 34.5 & 62.4 & 3.1 & 6.16 \\
Maize silage & 33.0 & 48.6 & 17.7 & 2.49 \\
\hline
\end{tabular}

Table 6. Feed intake, milk production, milk composition and bodyweight for the experimental period of 13 weeks (mean from 16 animals).

\begin{tabular}{|c|c|c|c|c|c|}
\hline & DP1 & PP2 & $\mathbf{M}^{3}$ & SEM & Sign \\
\hline Roughage (kg DM) & $9.2^{\mathrm{a} 4}$ & $8.8^{a}$ & $13.4^{b}$ & 0.10 & $P<0.01$ \\
\hline Concentrates (kg DM) & $13.7^{\mathrm{a}}$ & $13.3^{\mathrm{a}}$ & $8.6^{\mathrm{b}}$ & 0.11 & $P<0.01$ \\
\hline Beet pulp (kg DM) & 5.7 & 5.6 & - & 0.04 & NS \\
\hline Total intake (kg DM) & $22.9 \mathrm{a}$ & $22.1^{\mathrm{b}}$ & $22.0^{\mathrm{b}}$ & 0.21 & $P<0.05$ \\
\hline Net energy intake (MJ $\left.\mathrm{d}^{-1}\right)^{5}$ & $148^{a}$ & $144 b$ & $140^{c}$ & 1.36 & $P<0.01$ \\
\hline Protein intake $(\mathrm{g} \mathrm{dcp})^{6}$ & 2871 & 2768 & 2788 & 26.10 & NS \\
\hline Milk (kg) & 32.9 & 33.5 & 32.5 & 0.51 & NS \\
\hline Fat $(g)$ & 1459 & 1473 & 1458 & 24.61 & NS \\
\hline Protein (g) & 1084 & 1098 & 1031 & 14.87 & $P<0.10$ \\
\hline Fat $(\%)$ & 4.44 & 4.41 & 4.52 & 0.05 & NS \\
\hline Protein $(\%)$ & 3.32 & 3.30 & 3.19 & 0.03 & $P<0.10$ \\
\hline FCM $4 \%$ (kg) & 35.0 & 35.5 & 34.9 & 0.54 & NS \\
\hline Net energy req. (MJ) & 148 & 150 & 148 & 1.94 & NS \\
\hline Protein req. (g dcp) & 2607 & 2638 & 2598 & 35.32 & NS \\
\hline Energy intake/req. $(\%)^{7}$ & $100.6^{a}$ & $97.2^{\mathrm{a}}$ & $94.9 b$ & 1.12 & $P<0.05$ \\
\hline Protein intake/req. $(\%)^{8}$ & 111.3 & 106.3 & 108.1 & 1.29 & NS \\
\hline Body weight $(\mathrm{kg})$ & 624 & 627 & 626 & 6.25 & NS \\
\hline Body weight changes $(\mathrm{kg})$ & $-4 a$ & $-11^{a b}$ & $-18^{b}$ & 2.34 & $P<0.05$ \\
\hline
\end{tabular}

1 Dried beet pulp.

2 Pressed ensiled beet pulp.

3 Maize silage.

4 Figures with a different superscript differ significantly from each other.

5 Net energy intake = net energy intake according to Dutch Energy System (van Es, 1978).

$6 \mathrm{dcp}=$ digestible crude protein.

7 Energy intake/req. = ratio between energy intake and energy requirements.

8 Protein intake/req. = ratio between protein intake and protein requirements. 
The average results concerning feed intake, milk production and composition during the first 13 weeks of the lactation are displayed in Table 6. Total dry matter intake averaged approximately $22 \mathrm{~kg}$ DM per animal per day. The level of intake was equal to that observed in previous trials, when diets were also largely based on by-product ingredients (de Visser \& Tamminga, 1987; de Visser \& Steg, 1988). Total dry matter intake differed significantly between DP and the other treatments. Group M showed a slightly different pattern (Fig. 1), while the intake of group PP remained lower for the duration of the experiment.

Because of a lower DM intake the net energy intake was significantly lower for group PP compared to DP (Table 6). The energy intake was significantly lower for group M compared to both beet pulp groups (DP and PP). This can be accounted for by the lower DM intake and the lower energy value of maize silage compared to both beet pulps (Table 4). Compensation for the lower energy value of the maize silage with extra concentrates proved to be insufficient. The digestible crude protein intake did not differ significantly between groups.

Milk yield did not differ between groups, although production in relation to weeks post partum suggested a flatter curve for cows fed maize silage, while cows fed pressed beet pulp had a more pronounced peak (Fig. 2). Milk fat yields and per-

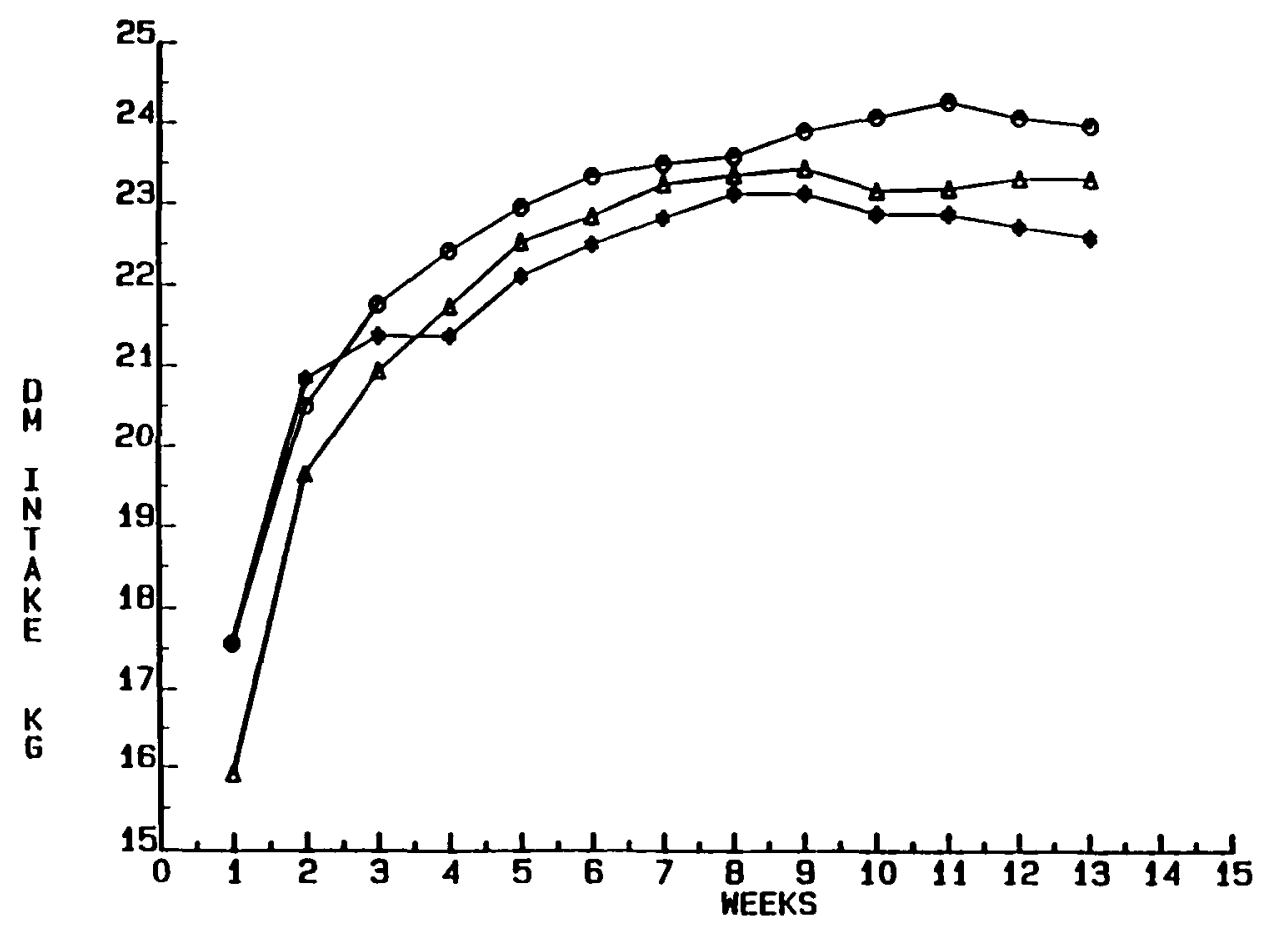

Fig. 1. Dry matter intake (kg). $0-0$ dried beet pulp, $\Delta-\Delta$ pressed beet pulp, $x-\times$ maize silage. 


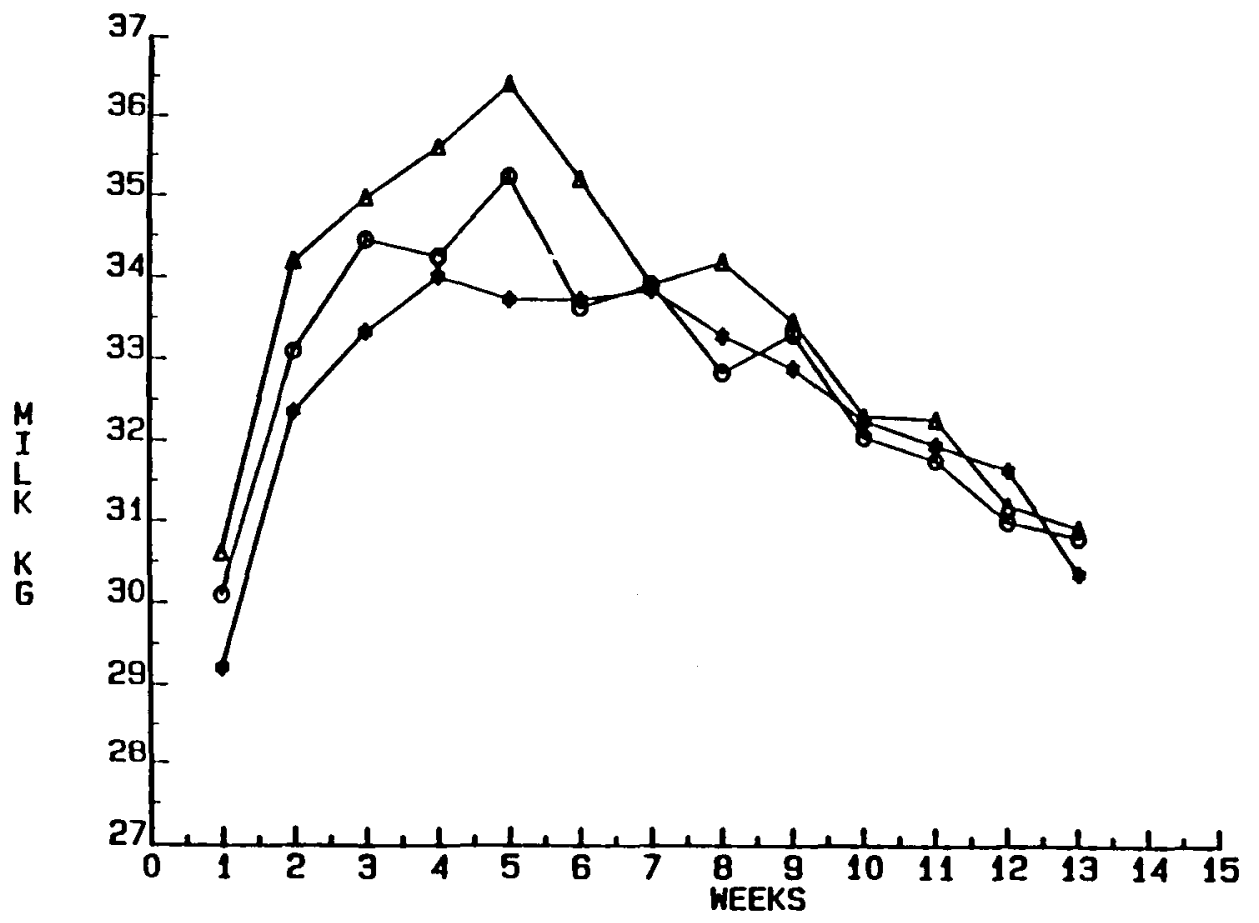

Fig. 2. Milk production $(\mathrm{kg}) .0-0$ dried beet pulp, $\Delta-\Delta$ pressed beet pulp, $\times-\times$ maize silage.

centages were not significantly different between groups, although group $\mathrm{M}$ tended $(P<0.10)$ towards a higher fat percentage. Milk protein yield and percentage did not differ significantly among groups, although cows fed maize silage tended to have the lowest protein yield and percentage $(P<0.10)$. Protein percentage did differ significantly from week 7 post partum onwards, being 3.27, 3.27 and 3.09 for DP, PP and $M$, respectively $(P<0.05$; Fig. 3$)$.

The energy intake/requirement ratio of all groups were in agreement with the body weight changes, based on group averages and according to the Dutch net energy lactation system (van Es, 1978). Individual energy balances and body weight changes were poorly related.

\section{Discussion}

The significantly lower DM intake of group PP compared to DP can be made plausible by two explanations. Firstly, due to the lower dry matter content of diet PP, animals had to consume larger quantities, which is very difficult during early lactation (Lahr et al., 1983). Secondly, due to the ensiling process, easily fermentable carbohydrates were used by micro-organisms in the silo during the ensiling process, which may have led to changes in the sources of energy available for micro- 


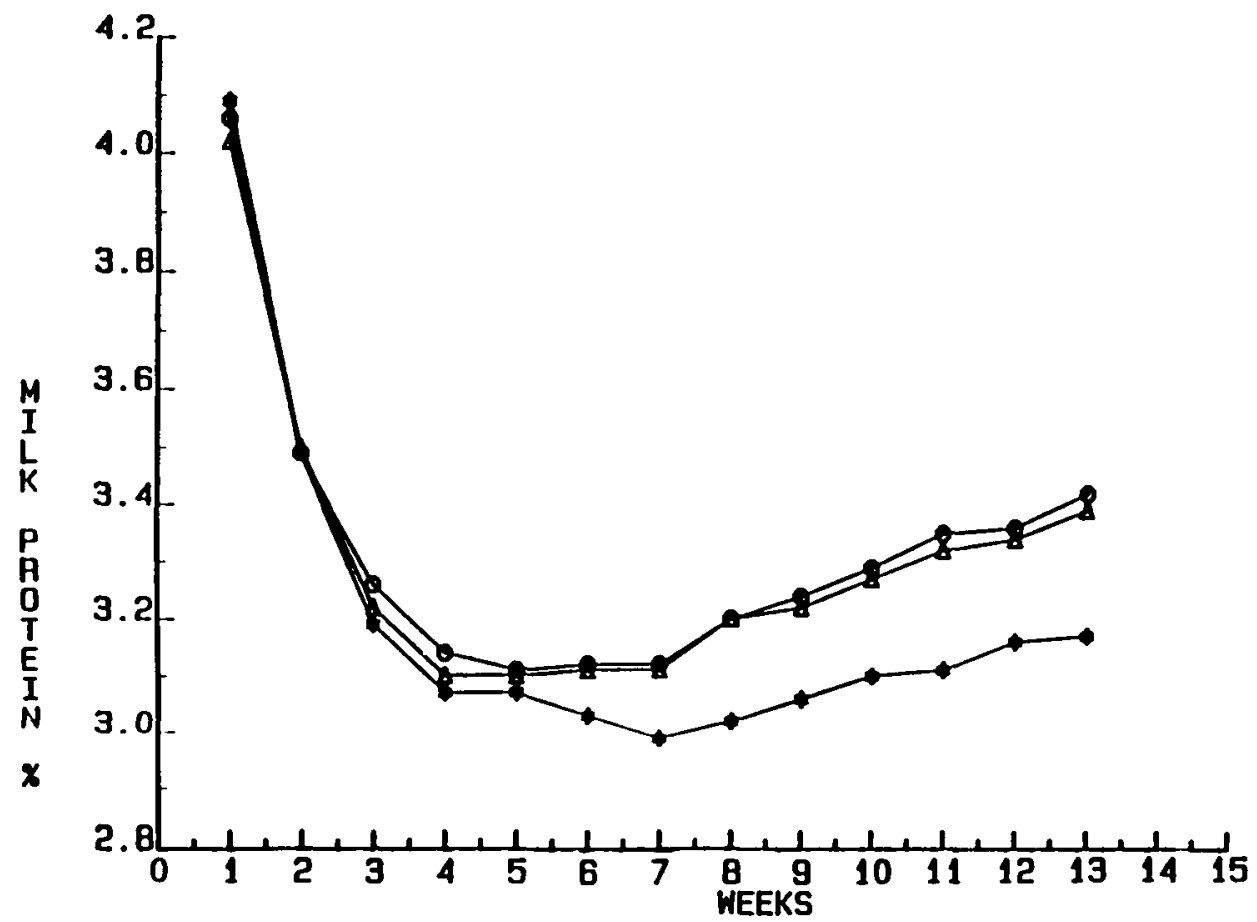

Fig. 3. Milk protein percentage. $0-0$ dried beet pulp, $\Delta-\Delta$ pressed beet pulp, $x-\times$ maize silage.

organisms in the rumen (carbohydrates versus volatile fatty acids and lactic acid), as suggested by van Soest (1982). Hemingway et al. (1986) fed similar amounts of dried and pressed beet pulp ( $5 \mathrm{~kg} \mathrm{DM})$. The total amount of feed consumed in their trial was lower than in our experiment, because animals were not fed ad libitum, but according to their requirements (milk production and bodyweight). In literature, several authors reported much higher intakes (approaching $10 \mathrm{~kg} \mathrm{DM}$ ) of dried or pressed beet pulp. They did not mention any problems with regard to intakes at such high levels (de Brabander et al., 1980; Andries et al., 1984; Haaksma, pers. comm.). In these trials, beet pulp was fed ad libitum and separately from the other ingredients. The significantly lower intake of group $\mathrm{M}$ compared to DP can be explained by the higher undegradable fraction and the lower rate of degradation of the potential degradable fraction of the OM (Table 5). Snijders (pers. comm.) found variable results when comparing rations with maize silage or beet pulp. In his experiments the DM intake was negatively influenced, when maize silages were fed with a lower quality (stage of maturity). Several researchers reported reductions in total dry matter intakes, when the roughage/concentrate ratio was decreased (Broster et al., 1978; Kirchgessner \& Schwarz, 1984). In these experiments the undegradable fraction and/or the rate of fermentation were probably negatively influenced, leading to a reduction of total DM intake. 
Milk yield did not differ significantly between dried and pressed beet pulp groups, which confirmed the findings from other experiments (Hemingway et al., 1986; Snijders, pers. comm.) when direct comparisons were made between both forms of beet pulp fed in early lactation. Comparing dried and pressed beet pulp in late lactation did not result in production differences either (Ronning \& Bath, 1962; Castle, 1972; Parkins et al., 1986). However, increasing responses of milk yield due to higher energy intakes are limited in late lactation (Broster, 1972). De Brabander et al. (1980) obtained higher milk yields when feeding pressed beet pulp in early lactation. However, in their trial low-energy concentrate components and even roughage was replaced by pressed beet pulp. The net energy intake was thus increased, leading to a higher milk output. After correction for higher energy intakes, differences were no longer significant. Milk yield did not differ significantly between either beet pulp groups and the maize silage group, in spite of the lower energy intake. Due to the lower energy intake the animals of group $M$ showed a lower milk yield peak than both the beet pulp groups. Snijders (pers. comm.) results showed occasional negative effects, when feeding maize silage instead of beet pulp, but these differences could be explained by lower energy intakes. When balanced rations containing large amounts of maize silage were fed, no negative effects on milk yield were found (Parrassin et al., 1979; de Visser \& Steg, 1987).

The similarity in fat percentage and yield of both beet pulp groups in our experiment confirmed findings elsewhere (Ronning \& Bath, 1962; Castle, 1972; Hemingway et al., 1986; Parkins et al., 1986). However, de Brabander et al. (1980) found lower milk fat percentages when feeding pressed beet pulp, probably caused by a higher roughage/concentrate ratio in the rations containing pressed beet pulp. The fat percentage was not significantly different between beet pulp groups and maize silage, but group $M$ tended to be highest $(P<0.10)$. This is in agreement with Snijders (pers. comm.) who also found a higher fat percentage for those groups fed maize silage. The companion study with rumen cannulated animals, fed with equal amounts of feed, showed no difference in total concentration of major volatile fatty acids or in their ratio. This indicates that no differences in milk fat yield and percentage might be expected, due to ruminal events (de Visser, unpublished results).

The milk protein percentage and yield did not differ significantly among groups fed beet pulp, which agreed with the results found by Ronning \& Bath (1962), Castle (1972), Hemingway et al. (1986), Parkins et al. (1986). However, de Brabander et al. (1980) found an increase in milk protein content and milk protein yield, but in their experiment energy intakes were higher, which might explain the higher milk protein output. The milk protein percentage over the total experimental period tended to differ between groups fed beet pulp and those fed maize silage, which agreed with the results of Snijders (pers. comm.). The lower energy intake is one of the possible explanations for the lower production and percentage of protein. The results of the accompanying fermentation study showed significantly increased concentrations of iso-acids and ammonia for the maize silage diet. Since the protein/energy ratio did not differ between treatments, this could be an indication of lower microbial protein synthesis (Miller, 1982; van Soest, 1982; Robinson et al., 1987). 


\section{Acknowledgements}

The authors wish to thank mssrs L. de Jong and J. Truin for taking care of the animals on the feeding trial and the staff of the metabolism unit for performing the digestibility studies with wethers.

The authors are particularly grateful for the financial support received from the Dutch Ministry of Economics and the Institute for Rational Sugar Production (IRS). Our special thanks goes to the CSM sugar mill 'Wittouck' in Breda for delivery of the sugar beet pulp.

\section{References}

Alvey, N. N. Galway \& P. Lane, 1982. An introduction to Genstat. Academic Press, London, 152 pp.

Andries, J. L., D. L. de Brabander, G. L. de Boever \& F. X. Buysse, 1984. Ensiled pressed sugarbeet pulp to appetite for dairy cattle. Landbouwtijdschrift 37: 999-1011 (in Dutch; summary, tables and figures in English).

Brabander, D. L. de, J. V. Aerts, C. V. Boucque \& F. X. Buysse, 1980. Effect of ensiled pressed sugarbeet pulp on the voluntary intake, milk yield and milk composition. Landbouwtijdschrift 33: 933-943 (in Dutch; summary, tables and figures in English).

Broster, W. H., 1972. Effect on milk yield of the cow of the level of feeding during lactation. Dairy Science Abstracts 34: 265-288.

Broster, W. H., J. D. Sutton \& J. A. Bines, 1978. Concentrate forage ratios for high yjelding dairy cows. In: W. Haresign \& D. Lewis (Eds), Recent advances in animal nutrition, pp. 99-126. Butterworth, London.

Castle, M. E., 1972. A comparative study of the feeding value of dried sugar beet pulp for milk production. Journal of Agricultural Science (Cambridge) 78: 371-377.

Cottyn, B. G., C. V. Boucque, J. V. Aerts, L. O. Fiems \& F. X. Buysse, 1980. The feeding value of pressed sugarbeet pulp. Landbouwtijdschrift 33: 945-961 (in Dutch; summary, tables and figures in English).

Es, A. J. H. van, 1978. Feed evaluation for ruminants. 1. The system in use from May 1977 onwards in the Netherlands. Livestock Production Science 5: 331-335.

Es, A. J. H. van \& J. M. van der Meer, 1980. Methods of analysis for predicting the energy and protein value of feeds for farm animals. In: A. J. H. van Es \& J. M. van der Meer (Eds), Proceedings workshop of methodology of analysis of feedingstuff for ruminants, pp. 10-50. Pudoc, Wageningen.

Hemingway, R. G., J. J. Parkins \& J. Frazer, 1986. Sugar beet pulp products for dairy cows. Animal Feed Science and Technology 15: 123-127.

Kelly, P., 1983. Sugar beet pulp - a review. Animal Feed Science and Technology 8: 1-18.

Kirchgessner, M. \& F. J. Schwarz, 1984. Einflussfaktoren auf die Grundfutteraufnahme bei Milchkuhen. Übersichten Tierernährung 12: 187-214.

Lahr, D. A., D. E. Otterby, D. G. Johnson, J. G. Linn \& G. Lundquist, 1983. Effects of moisture content of complete diets on feed intake and milk production by cows. Journal of Dairy Science 66: 1891-1900.

Merz, E., 1979. Neuer Automat zur Stickstoff-schnellbestimmung. Glas und Instrumenttechnik Fachzeitschrift für das Laboratorium, Mess-, Pruf- und Regulierungstechnik 14: 617-619.

Miller, E. L., 1982. The nitrogen needs of ruminants. Occasional Publication of British Society of Animal Production 6: 79-88.

Moran, J. B., C. Lemerle \& T. E. Trigg, 1988. The intake and digestion of maize silage based diets by dairy cows and sheep. Animal Feed Science and Technology 20: 299-312.

Parrassin, P. R., A. Hoden, M. Journet, C. Bazard, P. Faivre \& B. Guibert, 1979. Utilisation comparée des ensilage d'herbe et des ensilages de mais par les vaches laitières. Bulletin Technique Centre de Recherches Zootechnique et Vétérinair, Theix, Institute Nationale Recherches Agronomique 38: $35-42$. 


\section{H. DE VISSER AND V. A. HINDLE}

Parkins, J. J., R. G. Hemingway \& J. Frazer, 1986. A note on dried, molassed sugar beet pulp and unmolassed, pressed sugar beet pulp as comparative foods for dairy cows. Animal Production 43: 351-354.

Robinson, P. H., S. Tamminga \& A. M. van Vuuren, 1986. Influence of declining level of feed intake and varying the proportion of starch in the concentrate on rumen fermentation in dairy cows. Livestock Production Science 15: 173-189.

Robinson, P. H., S. Tamminga \& A. M. van Vuuren, 1987. Influence of wet vs. dry by-product ingredients and addition of branched-chain fatty acids and valerate to dairy diets. 2. Rumen fermentation and milk production. Netherlands Journal of Agricultural Science 35: 447-458.

Ronning, M. \& D. L. Bath, 1962. Relative milk production value of barley, dried beet pulp, molasses dried beet pulp, and concentrated steffen filtrated dried beet pulp. Journal of Dairy Science 45: 854-856.

Soest, P. van, 1982. Nutritional ecology of the ruminant. O \& B Books, Corvallis, OR, USA, 374 pp.

Tilley, J. M. \& R. E. Terry, 1963. A two-stage technique for the in vitro digestion of forage crops. Journal of the British Grassland Society 18: 104-111.

Verite, R., 1975. Utilisation comparée pour la production de lait de 3 rations à base de betteraves, de pulpes de betteraves ou d'ensilage de mais digestifs et métaboliques. Annales Zootechnique 24: 373-390.

Visser, H. de \& A. Steg, 1987. Utilization of by-products for dairy cow feeds. In: P. C. Garnsworthy (Ed), Proceedings of the 47th Easter School of Agriculture, Nottingham, pp. 378-394. Butterworths, London.

Visser, H. de \& S. Tamminga, 1987. Influence of wet vs. dry by-product ingredients and addition of branched-chain volatile fatty acids and valerate to dairy diets. 1 . Feed intake, milk production and milk composition. Netherlands Journal of Agricultural Science 35: 163-175. 